\title{
ISOLASI DAN KARAKTERISASI JAMUR ENDOFIT AKAR MERUNG (CAPTOSAPELTA TOMENTOSA)
}

\author{
Yunaedi*, Victoria Yulita F, Lisna Meylina, Rolan Rusli \\ Laboratorium Penelitian dan Pengembangan FARMAKA TROPIS Fakultas Farmasi \\ Universitas Mulawarman Samarinda Kalimantan Timur \\ *email:yuned283@gmail.com
}

\begin{abstract}
Endophytic fungi are a group of fungi that living in plant tissue and usually does not harm its host. Merung Plant (Coptosapelta tomentosa) by the people of Kutai Kartanegara, East Kalimantan has been used as a cure of rheumatism, increase stamina, drug of hypertension, diabetes mellitus, afrodisiaka, and anticancer. Endophytic fungi was isolated from merung root. Endophytic fungi was obtained 5 isolates, with isolates code JE1, JE2, JE3, JE4, and JE5. Isolate of JE1, JE2, JE3, JE4, and JE5, have characteristic were respectively black, dark green with orange edges, blackish-red, yellowish green, and green with white edges.
\end{abstract}

Keywords: Coptosapelta tomentosa, endophytic fungi, isolation

\begin{abstract}
ABSTRAK
Jamur endofit merupakan sekelompok jamur yang sebagian atau seluruh hidupnya berada dalam jaringan tumbuhan hidup dan biasanya tidak merugikan inangnya. Tumbuhan merung (Coptosapelta tomentosa) oleh masyarakat kutai Kartanegara, Kalimantan Timur sudah digunakan sebagai obat encok atau sakit pinggang, menambah stamina, obat hipertensi, diabetes melitus, afrodisiaka, serta antikanker. Jamur endofit diisolasi dari akar merung dan menghasilkan 5 isolat yang diberi kode isolat JE1, JE2, JE3, JE4, dan JE5. Isolat jamur endofit JE1, JE2, JE3, JE4, dan JE5 memiliki karakteristik berturut-turut adalah hitam, hijau tua dengan tepi orange, merah kehitaman, hijau kekuningan, dan hijau dengan tepi putih.
\end{abstract}

Kata kunci: Coptosapelta tomentosa, jamur endofit, isolasi

\section{PENDAHULUAN}

Merung merupakan salah satu tumbuhan yang hidup di daerah Kalimantan. Tumbuhan merung merupakan tumbuhan dengan arah tumbuh batang memanjat dan jenis batang berkayu, berwarna hijau jika muda dan berwarna coklat setelah tua, daunnya tipis berwarna hijau dan tepi bergerigi (Rezeky, 2009).

Tanaman Merung (Coptosapelta tomentosa) oleh masyarakat kutai Kartanegara, Kalimantan Timur sudah digunakan sebagai obat encok atau sakit pinggang, menambah stamina, digunakan juga sebagai obat hipertensi, diabetes melitus, afrodisiaka, serta antikanker. Bagian tanaman yang sering digunakan oleh masyarakat yaitu bagian akar. Beberapa aktivitas akar merung yang telah diuji yaitu aktivitas antimikroba, afrodisiaka, dan antioksidan. 
Menurut Tan dan Zou (2001), fungi endofit merupakan mikroorganisme yang hidup dalam jaringan tanaman dan mampu hidup dengan membentuk koloni dalam jaringan tanaman tanpa membahayakan tanaman inangnya. Setiap tanaman tingkat tinggi dapat mengandung beberapa mikroba, salah satunya fungi endofit yang mampu menghasilkan senyawa bioaktif atau metabolit sekunder sebagai akibat transfer genetik dari tanaman inangnya ke dalam fungi endofit. Jamur endofit memiliki kemampuan khusus untuk menghasilkan senyawa yang serupa dengan senyawa yang berasal dari tanaman inangnya, serta senyawa bioaktif lainnya.

Menurut kanti (2005), fungi endofit bersifat simbiosis mutualisme dengan tanaman inangnya. Manfaat yang diperoleh dari tanaman inang yakni peningkatan laju pertumbuhan tanaman inang, tahan terhadap serangan hama, penyakit dan kekeringan. Selain itu, fungi endofit dapat membatu proses penyerapan unsur hara yang dibutuhkan oleh tanaman untuk proses fotosintesis dan hasil fotosintesis dapat digunakan oleh fungi untuk mempertahankan kelangsungan hidupnya. Hubungan yang erat antara fungi endofit dan tanaman inangnya yakni transfer materi genetik satu dengan lainnya.

Dengan demikian potensi ini dapat dikembangkan dengan isolasi jamur endofit, khususnya pada akar tumbuhan merung karena secara tradisional, akar tumbuhan tersebut digunakan untuk mengobati sakit pinggang, diabetes, hipertensi, kanker, afrodisiaka, maupun penambah stamina. Oleh karena itu, dalam penelitian ini dilakukan isolasi dan karakterisasi jamur endofit yang terdapat pada akar tumbuhan merung [1].

\section{METODE PENELITIAN}

\section{ALAT DAN BAHAN}

Alat yang digunakan dalam penelitian ini yaitu timbangan analitik, autoklaf, inkubator, Laminar Air Flow, cawan petri, erlenmeyer, gelas kimia, spoit injeksi, hot plate, bisturi, mikroskop kamera dan alat penunjang lainnya. Bahan penelitian ini yaitu akar tumbuhan merung (Coptosapelta tomentosa). Untuk sterilisasi permukaan akar tumbuhan merung digunakan alkohol $70 \%$ dan $\mathrm{NaOCl} 5,25 \%$. Medium yang digunakan adalah Potato Dextrose Agar/ PDA (Merck) yang ditambahkan kloramfenikol selanjutnya disebut Potato Dextrose Agar Chloramphenicol (PDAC), Yeast Extract Agar/YEA (Merck) yang ditambahkan kloramfenikol selanjutnya disebut Yeast Extract Agar Chloramphenicol (YEAC) dan Malt Extract Agar/MEA (Merck) yang ditambahkan kloramfenikol selanjutnya disebut Malt Extract Agar Chloramfenicol (MEAC). Bahan yang digunakan untuk uji mikroskopik yaitu gliserin, kertas saring dan methylene blue.

\section{ISOLASI JAMUR ENDOFIT}

Isolasi jamur endofit dilakukan dengan metode tanam langsung. Akar tumbuhan merung dibersihkan terlebih dahulu menggunakan air suling yang mengalir untuk menghilangkan kotoran pada permukaan. Akar tumbuhan merung kemudian direndam dalam etanol $70 \%$ selama 1 menit, lalu dilanjutkan dengan perendaman dalam larutan natrium hipoklorit 5,3\% selama 3 menit, kemudian direndam kembali dalam etanol $70 \%$ selama 30 detik. Selanjutnya Akar tumbuhan merung ditiriskan dan dibagi menjadi beberapa potongan yang masing-masing berukuran lebih kurang $1 \times 1 \mathrm{~cm}$. Masing-masing potongan sampel diletakkan pada permukaan medium PDAC, YEAC, dan MEAC yang telah memadat dengan posisi bagian jaringan akar menempel pada medium, dalam satu cawan petri berisi 5 potongan sampel dengan tiga kali replikasi pada masing masing medium. Diinkubasi selama 7-14 hari pada suhu $25^{\circ} \mathrm{C}$ (Pancher et al, 2012). 


\section{PEMURNIAN JAMUR ENDOFIT}

Pemurnian dilakukan untuk memisahkan koloni jamur endofit hingga diperoleh isolat jamur endofit. Koloni jamur yang tumbuh di sekeliling sampel akar tumbuhan merung dimurnikan berdasarkan morfologi makroskopik yang diamati warna serta pertumbuhan koloni jamur. Masing-masing isolat jamur endofit yang diperoleh, kemudian dipindahkan menggunakan ose ke dalam media PDAC, YEAC, dan MEAC pada cawan petri yang baru untuk memisahkan koloni endofit dengan morfologi berbeda untuk dijadikan isolat tersendiri. Diinkubasi selama 5-7 hari pada suhu $25^{\circ} \mathrm{C}$, jika pada saat pengamatan ditemukan pertumbuhan koloni yang berbeda secara makroskopis maka dipisahkan kembali hingga diperoleh isolat murni.

\section{KARAKTERISASI ISOLAT JAMUR ENDOFIT}

Karakterisasi isolat jamur endofit dengan melakukan pengamatan ciri-ciri makroskopik dan mikroskopik. Karakterisasi secara makroskopik ini dilakukan dengan pengamatan isolat jamur endofit yang telah murni meliputi warna koloni, dan bentuk koloni. Karakterisasi secara mikroskopik ini dilakukan pengamatan menggunakan preparat isolat jamur endofit melalui mikroskop. (Sudantha, 2009). Terdapat dua jenis metode mikroskopik yaitu metode mikroskopik langsung. Metode mikroskopik langsung dilakukan dengan meneteskan methylen blue yang telah diinokulasikan isolat jamur endofit dan diamati menggunakan mikroskop. Sedangkan metode mikroskopik tidak langsung dilakukan dengan cara diinokulasikan isolat jamur endofit di atas medium PDA yang ada di object glass dan dibuat dalam kondisi lembab dengan gliserin yang ditetesi pada kertas saring sebagai pelapis cawan petri, kemudian diinkubasi selama 5-7 hari pada suhu $25^{\circ} \mathrm{C}$, selanjutnya diamati menggunakan mikroskop [2].

\section{HASIL DAN PEMBAHASAN}

a.

Isolasi Jamur Endofit

Setiap tumbuhan memiliki isolat jamur yang berbeda-beda meskipun isolat diambil dari bagian tumbuhan yang berbeda tetapi masih dalam satu tumbuhan. Isolasi jamur endofit terlebih dahulu dilakukan sterilisasi permukaan sampel sebelum ditanam pada medium. Proses sterilisasi permukaan ini dimaksudkan untuk dapat menjamin sterilitas permukaan sampel dari kontaminasi organisme. Proses sterilisasi tersebut menggunakan alkohol yang berfungsi untuk sterilisasi permukaan tetapi alkohol $70 \%$ memiliki spektrum yang sempit sehingga perlu dikombinasikan dengan bahan kimia lainnya dan biasanya dikombinasikan dengan $\mathrm{NaOCl} 5,3 \%$. Sampel yang telah disterilisasi permukaannya kemudian dipotong dan jaringannya ditempelkan pada medium yang telah memadat. Medium yang digunakan saat isolasi yaitu medium PDAC, YEAC, dan MEAC, penambahan kloramfenikol pada medium dilakukan untuk menekan pertumbuhan bakteri endofit dan bakteri patogen yang kemungkinan ikut tumbuh saat isolasi. Dari akar tumbuhan merung (Coptosapelta tomentosa), diperoleh total 5 isolat jamur endofit. Hasil isolasi dari akar tumbuhan merung dapat dilihat pada Gambar 1. Jamur endofit yang tumbuh pada potongan akar tumbuhan merung dimurnikan hingga memperoleh isolat jamur endofit. Pemisahan dilakukan berdasarkan warna dan bentuk koloni jamur yang kemudian dipindahkan ke dalam medium yang baru. Berdasarkan Gambar 1, hasil isolasi yang terlihat pada masing-masing cawan petri memiliki warna dan bentuk koloni yang berbeda. Isolat jamur endofit dengan kode isolat $\mathrm{JE}_{1}$ diisolasi dari akar tumbuhan merung dengan medium PDAC. Isolat jamur endofit dengan kode isolat $\mathrm{JE}_{2}$ diisolasi dari akar tumbuhan merung dengan medium YEAC, dan isolat $\mathrm{JE}_{3}$, dan $\mathrm{JE}_{4}$, dan $\mathrm{JE}_{5}$, diisolasi dari akar tumbuhan merung dengan medium MEAC. 
b. Karakterisasi Isolat Jamur Endofit

Isolat jamur endofit dari akar tumbuhan merung yang telah murni selanjutnya dikarakterisasi untuk mengetahui profil isolat jamur endofit. Hasil karakterisasi isolat jamur endofit akar tumbuhan merung dapat dilihat pada Gambar 1.
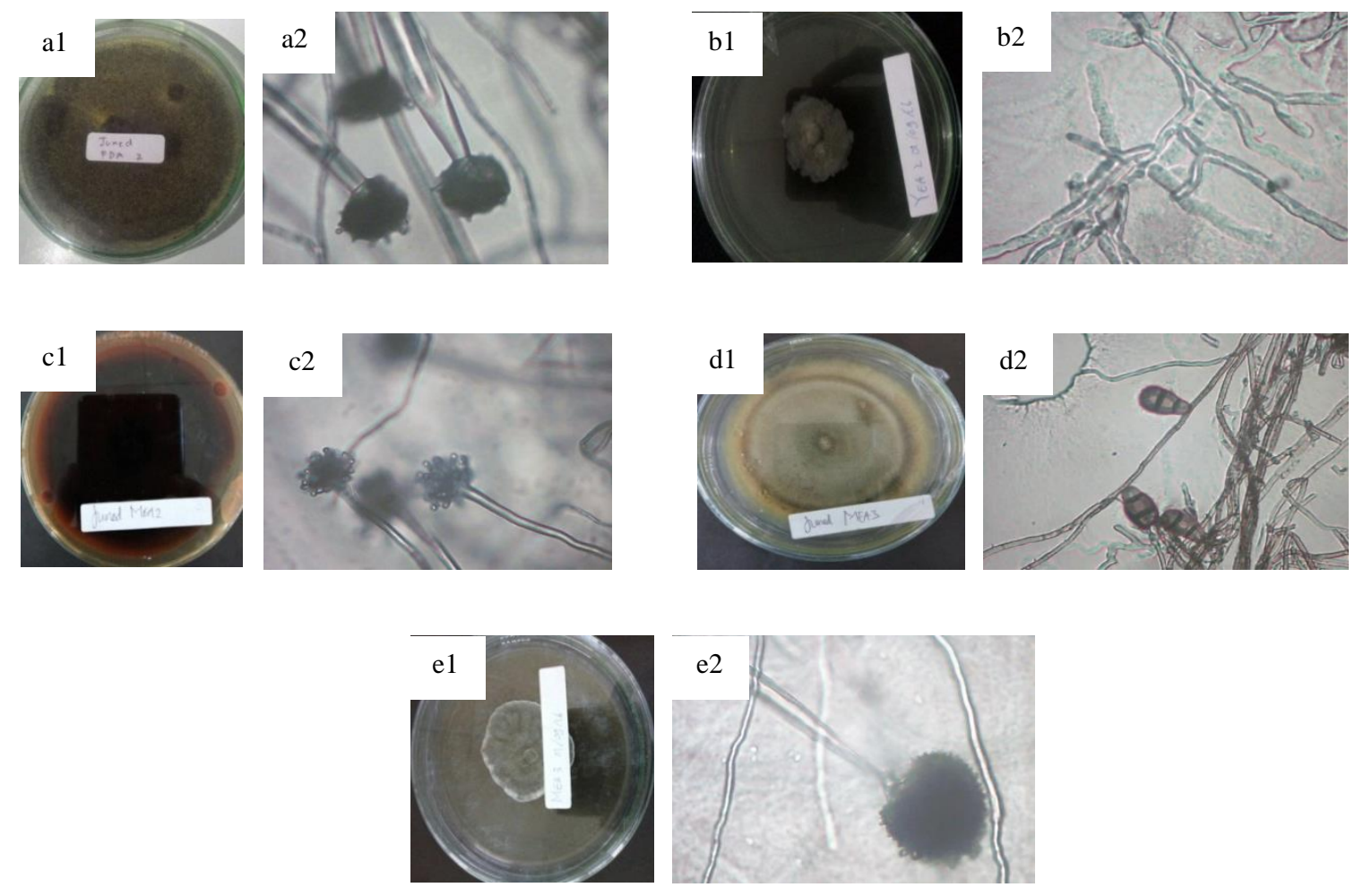

Gambar 1. Isolat jamur endofit akar tumbuhan merung (Coptosapelta tomentosa). Diperoleh lima isolat jamur endofit yaitu (a1) isolat jamur endofit JE1, (a2) hasil pengamatan mikroskopik isolat jamur endofit JE1, (b1) isolat jamur endofit JE2, (b2) hasil pengamatan mikroskopik isolat jamur endofit JE2, (c1) isolat jamur endofit JE3, (c2) hasil pengamatan mikroskopik isolat jamur endofit JE3, (d1) isolat jamur endofit JE4, (d2) hasil pengamatan mikroskopik isolat jamur endofit JE4, dan (e1) isolat jamur endofit JE5, (e2) hasil pengamatan mikroskopik isolat jamur endofit JE5.

Dari lima isolat jamur endofit akar tumbuhan merung hanya satu yang belum dapat diidentifikasi, karena tidak adanya konidia yang tumbuh. Sedangkan keempat isolat jamur endofit dapat diidentifikasi sebagai jamur Aspergillus dan Batryosphaeria [3]. 
Tabel 1. Karakteristik isolat jamur endofit secara makroskopik dan mikroskopik

\begin{tabular}{|c|c|c|c|c|c|}
\hline \multirow{2}{*}{ No } & \multirow{2}{*}{ Isolat } & \multicolumn{2}{|c|}{ Makroskopik } & \multirow{2}{*}{ Mikroskopik } & \multirow{2}{*}{ Genus } \\
\hline & & Warna & Bentuk & & \\
\hline 1 & JE1 & Hitam & $\begin{array}{l}\text { Bulat dengan tepi } \\
\text { halus }\end{array}$ & $\begin{array}{l}\text { Konidiofor, } \\
\text { konidia, hifa }\end{array}$ & Aspergillus \\
\hline 2 & JE2 & $\begin{array}{l}\text { Hijau tua dengan } \\
\text { tepi kuning }\end{array}$ & $\begin{array}{l}\text { Bulat dengan tepi } \\
\text { bergelombang }\end{array}$ & Hifa & Belum diketahui \\
\hline 3 & JE3 & Merah kehitaman & $\begin{array}{l}\text { Bulat dengan tepi } \\
\text { halus }\end{array}$ & $\begin{array}{l}\text { Konidiofor, } \\
\text { konidia, hifa }\end{array}$ & Aspergillus \\
\hline 4 & JE4 & Hijau kekuningan & $\begin{array}{l}\text { Bulat dengan tepi } \\
\text { halus }\end{array}$ & $\begin{array}{l}\text { Konidiofor, } \\
\text { konidia, hifa }\end{array}$ & Batryosphaeria \\
\hline 5 & JE5 & $\begin{array}{l}\text { Hijau dengan tepi } \\
\text { putih }\end{array}$ & $\begin{array}{l}\text { Bulat dengan tepi } \\
\text { halus }\end{array}$ & $\begin{array}{l}\text { Konidiofor, } \\
\text { konidia }\end{array}$ & Aspergillus \\
\hline
\end{tabular}

\section{KESIMPULAN}

Hasil isolasi jamur endofit akar tumbuhan merung (Coptosapelta tomentosa) diperoleh lima isolat jamur endofit. Isolat jamur endofit JE1, JE3, dan JE5 diduga merupakan genus Aspergillus, isolat jamur endofit JE4 diduga merupakan genus Batryosphaeria, dan isolat jamur endofit JE2 belum dapat diidentifikasi.

\section{DAFTAR PUSTAKA}

1. Rezeky, F.C. 2009. Aktivitas Afrodisiaka Ekstrak Metanol Akar Manuran Pada Mencit Putih Jantan. Fakultas MIPA UNLAM. Banjarbaru.

2. Tan, R. X and W. X Zou., 2001. Endophytes: a Rich Source of Functional Metabolites. Natural Product Reports. 18. (7). 448-459.

3. Kanti, A dan Muhammad, I. 2005. Isolasi dan Identifikasi Kapang pada Relung Rhizophere Tanaman Di Kawasan Cagar Alam Gunung Mutis, Timor, NTT. Bidang Zoologi. Pusat Penelitian Biologi-LIPI.

4. Pancher, M., M. Ceol, P.E. Comeo, C.M.O. Longa, S, Yousaf, I. Pertot, dan A. Campisano. 2012. Fungal Endophytic Communities in Grapevines (Vitix vinivera L.) Respond to Crop Management. Applied and Environmental Microbiology. 78. (12). 4308-4317.

5. Sudantha, IM, 2009. Uji Efektivitas Beberapa Isolat Jamur Endofit Antagonistik dalam Meningkatkan Ketahanan Terinduksi Beberapa Klon Vanili Terhadap Penyakit Busuk Batang. Agroteksos. 19. (2). 1-2.

6. $\quad$ Agusta, Andria. 2009. Biologi dan Kimia Jamur Endofit. ITB. Bandung.

7. Radji, M., 2005. Peranan Bioteknologi dan Mikroba Endofit dalam Pengembangan Obat Herbal. Majalah Ilmu Kefarmasian, 2. (3). 113-124.

8. Pelczar, M dan Chan. 2008. Dasar-dasar Mikrobiologi. UI Press : Jakarta. Jurnal Molekul 15. (11). 7961-7970.

9. Strobel, G., B. Daisy, et al. 2004. Natural Products from Endophytic Microorganism. Journal of Natural Products 67. (2). 257-268. 